\title{
PLASMA BIOCHEMISTRY REFERENCE VALUES OF WILD- CAUGHT SOUTHERN STINGRAYS (DASYATIS AMERICANA)
}

\author{
Danielle K. Cain, D.V.M., Craig A. Harms, D.V.M., Ph.D., Dipl. A.C.Z.M., and \\ Al Segars, M.S., D.V.M.
}

\begin{abstract}
Stingrays are prominent marine animals; however, there are few published reference values for their blood chemistry and hematology. Twenty-eight southern stingrays (Dasyatis americana) were caught using the bottom trawl nets of fishery-independent boats operated by the South Carolina Department of Natural Resources during June and July 2002 from Winyah Bay, South Carolina, to St. Augustine, Florida. Median values of blood and plasma obtained from live animals promptly after capture are as follows: packed cell volume $=0.22 \mathrm{~L} / \mathrm{L}(22 \%)$, total solids (TS) $=$ $56.5 \mathrm{~g} / \mathrm{L}(5.65 \mathrm{~g} / \mathrm{dl})$, total protein $(\mathrm{TP})=26 \mathrm{~g} / \mathrm{L}(2.6 \mathrm{~g} / \mathrm{dl})$, sodium $=315 \mathrm{mmol} / \mathrm{L}$, potassium $=4.95 \mathrm{mmol} / \mathrm{L}$, chloride $=342 \mathrm{mmol} / \mathrm{L}$, calcium $=4.12 \mathrm{mmol} / \mathrm{L}(16.5 \mathrm{mg} / \mathrm{dl})$, phosphorus $=1.5 \mathrm{mmol} / \mathrm{L}(4.7 \mathrm{mg} / \mathrm{dl})$, urea nitrogen $=444$ $\mathrm{mmol} / \mathrm{L}(1,243 \mathrm{mg} / \mathrm{dl})$, glucose $=1.69 \mathrm{mmol} / \mathrm{L}(30 \mathrm{mg} / \mathrm{dl})$, aspartate aminotransferase $=14.5 \mathrm{U} / \mathrm{L}$, creatine phosphokinase $=80.5 \mathrm{U} / \mathrm{L}$, osmolality $=1065 \mathrm{mOsm} / \mathrm{kg}$, and lactate $=3.1 \mathrm{mmol} / \mathrm{L}$. Bicarbonate was less than the low end of the instrument range $(5 \mathrm{mmol} / \mathrm{L})$ in all but three samples. Anion gap was negative in all samples. Albumin was less than the low end of the instrument range $(1 \mathrm{~g} / \mathrm{dl})$ in all except one sample. Osmolality was significantly higher in the rays caught in the southern region. TS and TP values were linearly related to each other, and the equation for the fitted line is $\mathrm{TS}=(11.61 \times \mathrm{TP})+25.4($ in $\mathrm{g} / \mathrm{L})[$ or $\mathrm{TS}=(1.161 \times \mathrm{TP})+2.54(\mathrm{in} \mathrm{g} / \mathrm{dl})]$. The reference ranges reported in this study can be used to aid in the management of aquarium stingrays and to create a baseline for health monitoring of the wild Dasyatis spp.

Key words: Dasyatis americana, plasma biochemistry, southern stingray, reference range.
\end{abstract}

\section{INTRODUCTION}

There are about 800 species of elasmobranch fishes, primarily sharks, skates, and rays, throughout the world's oceans, ${ }^{12}$ including $>450$ species in the order Rajiformes (skates and rays). Some of the latter groups are familiar to humans, ${ }^{14}$ although little is known about their veterinary care. Although little is known about elasmobranch blood chemistry values, sharks have received some study in this regard. $4,6,10,11,21,22,24,25$ Studies involving skates and rays have focused largely on electrolytes and osmolar

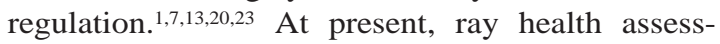
ments must use data extrapolated from sharks or obtained in-house. We, therefore, initiated a study to document blood chemistry and hematology values for dasyatid stingrays collected in the coastal

From the Department of Clinical Sciences and the Environmental Consortium, College of Veterinary Medicine, North Carolina State University, 4700 Hillsborough Street, Raleigh, North Carolina 27606, USA (Cain, Harms); the Department of Clinical Sciences, College of Veterinary Medicine, Center for Marine Sciences and Technology, North Carolina State University, 303 College Circle, Morehead City, North Carolina 28557, USA (Harms); and the South Carolina Department of Natural Resources, 32 Fiddler Drive, Beaufort, South Carolina 29902, USA (Segars). Present address (Cain): VCA Emergency Animal Hospital and Referral Center, 2317 Hotel Circle South, San Diego, California 92108, USA. Correspondence should be directed to Dr. Harms. waters of South Carolina, Georgia, and northern Florida.

\section{MATERIALS AND METHODS}

\section{Specimen collection}

Southern stingrays (Dasyatis americana) were collected as by-catch in conjunction with a trawl survey for sea turtle species in June and July 2002. Live rays were collected aboard three fishery-independent boats (i.e., research boats, not part of a commercial fishery) between Cape Romain, South Carolina, USA $\left(32^{\circ} 58^{\prime} \mathrm{N}, 79^{\circ} 28^{\prime} \mathrm{W}\right)$ and St. Augustine, Florida, USA $\left(30^{\circ} 25^{\prime} \mathrm{N}, 81^{\circ} 23^{\prime} \mathrm{W}\right)$. All survey trawls were conducted inshore of the Gulf Stream, between the 4- and 12-m-depth contours and 0.8$8.8 \mathrm{~km}$ offshore. Two boats sampled waters north of St. Catherine's Sound, Georgia, USA $\left(31^{\circ} 43^{\prime} \mathrm{N}\right.$, $81^{\circ} 08^{\prime} \mathrm{W}$ ), and a third boat sampled waters south of this sound to St. Augustine, Florida, USA. Identical sampling methods were followed on all boats. Stretch mesh $(10-20 \mathrm{~cm})$ nets were dragged with a $18-\mathrm{m}$ footrope on the bottom for $30 \mathrm{~min}$ in water at depths of 4-12 m. Sea surface temperatures for the waters sampled ranged from 23.9 to $27.7^{\circ} \mathrm{C}$. ${ }^{9}$ Salinity and bottom temperature were not measured.

Only individuals with a healthy appearance (i.e., tails intact and no visible external lesions) were studied. All rays were processed quickly; the maximum possible net time was $38 \mathrm{~min}$. Rays that were 
caught along with sea turtles were not studied because they could not be processed quickly enough. Sex was determined based on the presence or absence of claspers. Straight disk width (to the nearest whole centimeter) was recorded using a measuring board (Wildco Wildlife Supply Co., Buffalo, New York 14216, USA) or a nylon tape measure. Body weight (to the nearest $0.1 \mathrm{~kg}$ ) was determined with one of the two spring scales depending on size (AMETEK Test and Calibration Instruments Division, Largo, Florida 33773, USA, Model in-50, $0.0-25.0 \mathrm{~kg}$ in $0.25 \mathrm{-kg}$ increments, and Model in$10,0.0-5.0 \mathrm{~kg}$ in $0.2-\mathrm{kg}$ increments).

Four species of dasyatid stingray occur in the waters sampled. Identification of southern stingrays was based on the species occurrence in the sampling locations, and physical characteristics of disk shape, tail folds, and absence of spines on body and tail. ${ }^{8} 18$ Distinction of bluntnose stingrays, Dasyatis sayi, from $D$. americana at disk widths less than $40 \mathrm{~cm}$, and distinction of $D$. americana from roughtail stingrays, Dasyatis centroura, at disk widths greater than $60 \mathrm{~cm}$ can be difficult. To increase the certainty of consistent identification, stingrays between 40 and $60 \mathrm{~cm}$ were preferentially sampled in this study. Inclusion of few of the closely related and physically similar $D$. centroura in the samples cannot be ruled out. However, D. centroura typically bears rough tubercles on sides and tail, and is rare south of Cape Hatteras, North Carolina. ${ }^{18}$

\section{Blood collection, processing, and analysis}

After physical measurements and information were recorded, a single blood sample was collected. Time from being brought on board to time of blood collection was recorded to the nearest minute. Only blood samples collected within 5 min of boarding were included for analysis. Animals were placed in dorsal recumbency, and their tails were restrained manually. Blood was drawn by cardiac puncture using a 3 -ml syringe with a 22 -ga $(0.7 \mathrm{~mm} \times 40 \mathrm{~mm})$ needle and then transferred to 5-ml lithium heparin vacutainer tubes (Becton Dickinson, Franklin Lakes, New Jersey 07417, USA). Initial attempts to collect blood from the tail vein led to longer times on deck for processing, which was deemed detrimental to postrelease survival chances, and poorer quality samples with hemolysis, clotting, and smaller volumes. Because of the spongy nature of the endocardium and myocardium of fish, ${ }^{15}$ cardiac puncture, when necessary, is less prone to complications than may be the case with mammals. When observation was possible, all rays included in this study swam away after blood sampling, corresponding to the best condition scores (condition 1 or 2, good or fair) used in a study of shark serum chemistry values after gill-net capture. ${ }^{11}$

Blood was shielded from sunlight and transferred within 3 min to the ship's cabin (air-conditioned or cooled by sea breeze) and processed within $15 \mathrm{~min}$ of collection. Packed cell volume was measured from a subsample of blood, transferred into a microcapillary tube, and centrifuged for $5 \mathrm{~min}$ in a 14,000 g microcapillary centrifuge (Model MB, International Equipment Company, Needham Heights, Massachusetts 02494, USA) at ambient temperature. Vacutainer tubes were centrifuged for $5 \mathrm{~min}$ at ambient temperature using a $1000 \mathrm{~g}$ Adams Sero-Fuge Connecticut 1600 centrifuge (Clay Adams Company, Parsippany, New Jersey 07054, USA). Plasma total solids (TS) were measured by refractometry (RHC-200ATC Refractometer, Westover Scientific, Woodinville, Washington 98077, USA). The remaining plasma was transferred to 1.5-ml cryovials and stored in liquid nitrogen tanks on board the research vessel for several days. Plasma was stored at $-80^{\circ} \mathrm{C}$ on shore and transported on dry ice for laboratory analyses, performed 5-9 wk after collection. Plasma lactates were measured 18 mo after collection from duplicate aliquots.

Fifteen plasma analytes were measured using automated bichromatic spectrophotometry, ion electrolysis, and freezing-point osmometer readings. Automated bichromatic spectrophotometry with a Roche/Hitachi 912 Clinical Chemistry System (Roche Diagnostics, Indianapolis, Indiana 46256, USA) was used to measure 11 analytes (albumin, aspartate aminotransferase, bicarbonate, $\mathrm{Ca}$, creatine kinase, glucose, lactate dehydrogenase [LDH], phosphorus, total protein [TP], urea nitrogen, and lactate). An ion-selective electrode on the Roche/ Hitachi 912 machine was used to measure three analytes $(\mathrm{Na}, \mathrm{K}$, and $\mathrm{Cl})$. A freezing-point osmometer (Advanced Micro-Osmometer, Model 3MO, Advanced Instruments Inc., Needham Heights, Massachusetts 02494, USA) was used to measure plasma osmolality. For any given analyte, all samples were run on the same day, with the same calibration.

\section{Statistical analyses}

Statistical analyses were performed with a commercial software package (JMP 5.0, SAS Institute, Cary, North Carolina 27511, USA). Data were tested for normality using a Shapiro-Wilk test. Because many of these data were not normally distributed, nonparametric statistics were used (except for correlations of TS and TP concentrations), and summary statistics are reported as median, 10th and 90th percentiles. Kendall tau test was used to test 
Table 1. Descriptive statistics for blood chemistry parameters analyzed for 28 dasyatid stingrays collected in coastal waters of South Carolina, Georgia, and northern Florida. Most values for bicarbonate, albumin, and lactate dehydrogenase fell below instrument measurement ranges $(5 \mathrm{mmol} / \mathrm{L}, 1 \mathrm{~g} / \mathrm{dl}$, and $5 \mathrm{U} / \mathrm{L}$, respectively) and were not included.

\begin{tabular}{|c|c|c|c|}
\hline Parameter & Median & 10th percentile & 90th percentile \\
\hline Packed cell volume, L/L (\%) & $0.22(22)$ & $0.15(15)$ & $0.25(25)$ \\
\hline Total solids, g/L (g/dl) & $56 \quad(5.6)$ & $42 \quad(4.2)$ & $60 \quad(6.0)$ \\
\hline Total protein, g/L (g/dl) & $(2.6)$ & $(1.6)$ & $32 \quad(3.2)$ \\
\hline Sodium, $\mathrm{mmol} / \mathrm{L}$ & 315 & 295.9 & 326.2 \\
\hline Potassium, mmol/L & 5.0 & 3.2 & 6.4 \\
\hline Chloride, $\mathrm{mmol} / \mathrm{L}$ & 342 & 301 & 362 \\
\hline Calcium, mmol/L (mg/dl) & $4.12(16.5)$ & $3.01(12.06)$ & $4.82(19.3)$ \\
\hline Phosphorus, mmol/L (mg/dl) & $1.5 \quad(4.7)$ & $0.98(3.0)$ & $2.1 \quad(6.4)$ \\
\hline Urea nitrogen, $\mathrm{mmol} / \mathrm{L}(\mathrm{mg} / \mathrm{dl})$ & $444 \quad(1,243)$ & $423.0 \quad(1,184.9)$ & $461.6 \quad(1,293.1)$ \\
\hline Glucose, $\mathrm{mmol} / \mathrm{L}(\mathrm{mg} / \mathrm{dl})$ & $1.69(30.5)$ & $0.94(16.9)$ & $2.35(42.4)$ \\
\hline Aspartate aminotransferase, U/L & 14.5 & 3.6 & 61.2 \\
\hline Creatine kinase, U/L & 80.5 & 11.7 & 296.5 \\
\hline Lactate, $\mathrm{mmol} / \mathrm{L}$ & 3.1 & $<2.0$ & 6.2 \\
\hline Osmolality, mOsm & 1,065 & $1,007.6$ & $1,144.3$ \\
\hline
\end{tabular}

for association of size (body weight and disk width) with blood and plasma analytes, for association of time on deck before sampling (1-5 min) with blood and plasma analytes, and for association of lactate with glucose. Wilcoxon rank sum test followed by sequential Bonferroni correction for multiple comparisons ${ }^{17}$ was used to compare values by sex and by region (north versus south). Sex ratios were compared between regions by chi-square. A leastsquares linear regression was used to determine the correlation between TS and TP values. Statistical significance was set at $P<0.05$. Data are reported in both standard and SI units.

\section{RESULTS}

Blood samples from 28 D. americana were collected. Eight male and nine female stingrays were collected in the northern region of the sampling area, compared with six male and five female stingrays collected in the southern region. No significant differences in sex ratios were detected between regions.

Median disk width was $40 \mathrm{~cm}$ (range $=32-68.7$ $\mathrm{cm}$ ) for stingrays collected in the northern region and $42 \mathrm{~cm}(36-53 \mathrm{~cm})$ for stingrays collected in the southern region. Median body weight was 1.8 $\mathrm{kg}(1.1-14 \mathrm{~kg})$ and $2.0 \mathrm{~kg}(1.4-13 \mathrm{~kg})$ for stingrays collected in the northern and southern regions of the sampling area, respectively. The overall median disk width of rays collected was $41 \mathrm{~cm}$ (32-68.7 $\mathrm{cm})$ and the median overall weight was $1.95 \mathrm{~kg}$ $(1.1-14.0 \mathrm{~kg})$. No differences in disk width or body weight with respect to region were detected.

Measured values for three parameters were consistently below the minimum detectable levels for our equipment. Bicarbonate was less than $5 \mathrm{mmol} /$ $\mathrm{L}$ in all but three samples, and levels in these three were $5 \mathrm{mmol} / \mathrm{L}$. Although we were unable to calculate anion gap directly, insertion of the highest possible value for bicarbonate into the anion gap equation $(\mathrm{Na}+\mathrm{K})-\left(\mathrm{Cl}+\mathrm{HCO}_{3}\right)$ resulted in a negative value for all samples. Albumin was less than $1 \mathrm{~g} / \mathrm{dl}$ in all but one sample with a value of $1.1 \mathrm{~g} / \mathrm{dl}$. In all samples, $\mathrm{LDH}$ was lower than $5 \mathrm{U} /$ L. In addition, lactate values were less than 2 $\mathrm{mmol} / \mathrm{L}$ in six samples. For statistical comparisons, a value of $2.0 \mathrm{mmol} / \mathrm{L}$ was assigned to these low lactate values.

Descriptive statistics for blood chemistry parameters are shown in Table 1. Regional differences were not detected for any value except osmolality, which was significantly higher $(P<0.0001)$ in the southern range (median $=1096$ mOsm [10th and 90th percentiles $1058,1188 \mathrm{mOsm}], n=11$ ) than in the north (median $=1049$ mOsm [1004, 1073 mOsm], $n=17$ ). No significant differences in blood chemistry were detected with respect to weight, disk width, or sex. Plasma lactate and $\mathrm{Ca}$ were the only values associated with time on deck (from 1 to $5 \mathrm{~min}$ ), being significantly but not strongly associated positively (Kendall tau $=0.30$, $P=0.045$ for lactate; Kendall tau $=0.31, P=$ 0.036 for calcium, with no corrections for multiple comparisons). Plasma lactate was significantly but not strongly associated positively with glucose (Kendall tau $=0.36, P=0.008)$. TS and TP values were linearly related $\left(R^{2}=0.91, P<0.0001\right)$, and the equation for the fitted line is $\mathrm{TS}=(1.161 \times$ $\mathrm{TP})+2.54$, where TS and TP are in grams per deciliter (Fig. 1). 


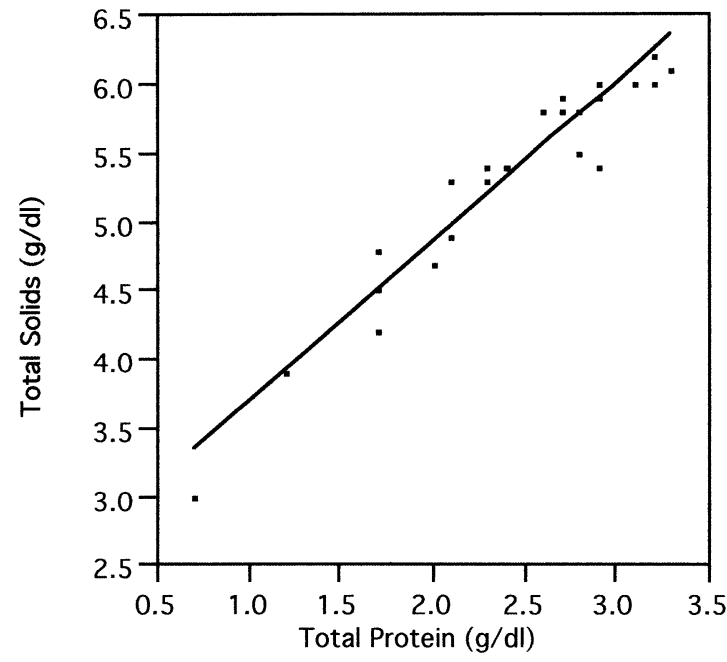

Figure 1. Southern stingray total protein and total solids concentrations were significantly correlated (leastsquares linear regression, $n=28, R^{2}=0.91, P<0.0001$ ). The equation for the fitted line is total solids (TS) = $(11.61 \times$ total proteins $[\mathrm{TP}])+25.4($ in $\mathrm{g} / \mathrm{L})$ [or $\mathrm{TS}=$ $(1.161 \times \mathrm{TP})+2.54($ in $\mathrm{g} / \mathrm{dl})]$.

\section{DISCUSSION}

There was unavoidably some stress associated with the capture of stingrays in this study, possibly including hypoxia and excessive exertion. However, based on lactate values and subjective assessment, the methods used in this study were likely less stressful than methods used in some previous studies using hook and line, entanglement nets, dredges, and longer soak times. ${ }^{5,11,13,24,25}$ The degree of struggling and exhaustion with capture significantly affects an elasmobranch's blood chemistry and ability to survive postrelease. ${ }^{11}$ In capture situations, benthic stingrays may have an advantage over some shark species because they are naturally more sedentary ${ }^{2}$ and are neither facultative nor obligatory ram ventilators. Sharks (specifically bonnetheads, Sphyrna tiburo, and black-tip sharks, Carcharhinus limbatus) may struggle dramatically in anchored gill nets, often becoming tightly entangled and exhausted. ${ }^{11}$ Once on board, stingrays are less likely to struggle as much or for as long a period of time as the sharks (Cain and Al Seegars, pers. obs.). Lactate values did increase with time on board (from 1 to $5 \mathrm{~min}$ ) before sampling, but the median value $(3.1 \mathrm{mmol} / \mathrm{L})$ was less than that found even in condition 1 animals in a study of sharks captured by gill net $(3.9,4.7$, and $6.3 \mathrm{mmol} /$ L for bonnethead, black - tip, and bull [Carcharhinus leucas] sharks, respectively ${ }^{11}$ and considerably less than that found in condition 5 (moribund) animals $(12.0 \mathrm{mmol} / \mathrm{L}$ for all three species, which was the instrument maximum) and in blue sharks (Prionace glauca) and mako sharks (Isurus oxyrinchus) captured by hook and line (mean values of 9 and $13 \mathrm{mmol} / \mathrm{L}$ for blue sharks and mako sharks, respectively, in one study, and $16.0 \mathrm{mmol} / \mathrm{L}$ for mako sharks in another study). ${ }^{24,25}$ Because blood was not collected into sodium fluoride tubes to halt glycolysis by the red blood cells immediately, as is recommended for measuring lactate, these values may have increased within the time required $(<20$ min) to separate plasma. ${ }^{3}$ In a study of cats, allowing blood to clot at $25^{\circ} \mathrm{C}$ and separating serum within 15-30 min of collection caused lactate values of control cats to increase by a mean of 0.4 $\mathrm{mmol} / \mathrm{L}$ over samples collected into sodium fluoride tubes, and by a mean of $1.2 \mathrm{mmol} / \mathrm{L}$ from hyperthyroid cats. ${ }^{3}$ Blood samples in the cited studies of shark capture effects were also not collected into sodium fluoride tubes. ${ }^{11,24,25}$

The urea nitrogen values for dasyatid stingrays were higher than values recorded for several shark species. ${ }^{22}$ These values are typically high in elasmobranchs, contributing to the high osmolality of their plasma, which is slightly hyperosmotic to seawater. Hyperosmolality, maintained by urea and trimethylamine oxides, in addition to plasma electrolytes, allows a passive influx of water from the environment. ${ }^{19}$ The plasma osmolality values in these rays were similar to values recorded in $S$. tiburo captured in the same area $1 \mathrm{yr}$ ago. ${ }^{6}$ Sodium and chloride values were also higher in these dasyatid stingrays relative to most sharks; however, it is not uncommon to see high concentrations of these electrolytes in elasmobranchs, and to a lesser extent, in other marine fish. ${ }^{21}$

Glucose concentrations vary greatly between species and have been shown to increase with a fish stress response. ${ }^{11,16}$ The glucose concentrations in these stingrays were low when compared with most sharks, birds, or mammals, but are similar to values seen in some koi. ${ }^{5}$ When compared with the skate, Raja erinacea, the glucose values of these $D$. americana overlap with the low end of the range. ${ }^{7}$ In sharks captured by gill net, glucose values decreased with worsening condition score, from poor to moribund or dead (condition score 3-5), ${ }^{11}$ but the shark species noted to struggle the least in the gill net had the lowest glucose values when comparing individuals in good condition, ${ }^{11}$ and the rays in the present study would all have fallen in the good to fair condition categories (condition score 1-2) used in the shark gill net paper. Median lactate values for these trawl-captured rays were lower than those for any of the three shark species of any 
condition score captured by gill net, ${ }^{11}$ and ray lactate values were positively rather than negatively associated with glucose values, indicating that excessive struggle was not a factor in the low glucose values of the rays. Because sample handling was nearly identical to a previous study of bonnethead shark plasma chemistry values, ${ }^{6}$ we believe that these glucose values are not artifactually low.

Osmolality values were significantly greater for rays collected in the southern region than in the northern region. Given that size and sex did not appear to influence blood chemistry, and that similar-sized rays in similar sex ratios were collected in both regions of the study area, higher osmolality in the southern range may reflect some phenomena of oceanographic features that differ between regions. Differences in osmolality in rays collected in the northern and southern regions may also have been influenced by collection and handling. Although sampling protocol was similar between regions, and only stingrays able to be processed promptly on arrival on deck were included in this study, it was impossible to know exactly how much time each stingray spent in the net. For example, an animal caught just before bringing the nets onboard would have spent approximately $30 \mathrm{~min}$ (trawl duration) less time in the nets than an animal caught immediately after the trawl began. However, because comparable numbers of rays were sampled in each location, it is unlikely that trawl time was skewed one way or another in either range. Whatever the reason for the differences in osmolality between the northern and southern ranges, it is evident that no single sample population, sample time, or sample location can be used to establish a universal reference range. Plasma chemistry values are also expected to change slightly with the hormonal changes associated with reproductive cycles.

The disparity between TS, measured by refractometry, and TP, measured by bichromatic spectrophotometry, agrees in general with previous reports ${ }^{6,22}$ and can be attributed to the contribution of urea nitrogen and trimethylamine oxide to the TS value. The disparity differs in specifics, however, with the equation of the fitted line for $D$. americana being $\mathrm{TS}=(11.61 \times \mathrm{TP})+25.4($ in $\mathrm{g} / \mathrm{L})$ [or TS $=(1.161 \times \mathrm{TP})+2.54($ in $\mathrm{g} / \mathrm{dl})]$, and that for $S$. tiburo being TS $=(10.06 \times \mathrm{TP})+33.18($ in $\mathrm{g} / \mathrm{L})$ [or TS $=(1.006 \times \mathrm{TP})+3.318($ in $\mathrm{g} / \mathrm{dl})] .^{6}$ These differences in slope and y-intercept between two elasmobranch species indicate that refractometry measurement of TS may not be convertible to TP with a single formula for all elasmobranchs.

\section{CONCLUSIONS}

Blood chemistry data from this study can provide a helpful reference for evaluating the health of captive stingrays. The expanded set of analytes and the reasonably large sample size add to the limited data previously available to veterinarians and researchers working with stingrays.

Acknowledgments: Many people provided invaluable assistance during the course of this project. We thank Dr. M. Stoskopf, Dr. G. Lewbart, Dr. D. Rotstein, S. Ballantyne, Dr. M. Correa, and M. Arendt. Funding for this study was provided by the Marine Resources Division of the South Carolina Department of Natural Resources, the North Carolina State University Support Fund for Aquatic Animal Medicine, and the North Carolina State University College of Veterinary Medicine. Trawling activities were conducted under National Marine Fisheries Service Endangered Species Permit \#1245 and scientific collection permit issued by the South Carolina Department of Natural Resources.

\section{LITERATURE CITED}

1. Bittneer, A., and S. Lang. 1980. Some aspects of the osmoregulation of Amazonian freshwater stingrays (Potamotrygon hystrix). 1. Serum osmolality, sodium and chloride content, water content, hematocrit and urea level. Comp. Biochem. Physiol. 67A: 9-13.

2. Böhlke, J. E., and C. C. G. Chaplin. 1993. Fishes of the Bahamas and Adjacent Tropical Waters, 2nd ed.. University of Texas Press, Austin, Texas.

3. Christopher, M. M., and S. O’Neill. 2000. Effect of specimen collection and storage on blood glucose and lactate concentrations in healthy, hyperthyroid and diabetic cats. Vet. Clin. Pathol. 29: 22-28.

4. Cliff G., and G. D. Thurman. 1984. Pathological and physiological effects of stress during capture and transport in the juvenile dusky shark, Carcharhinus obscurus. Comp. Biochem. Physiol. 78A: 167-173.

5. Groff, J. M., and J. G. Zinkl. 1999. Hematology and clinical chemistry of cyprinid fish. Vet. Clin. N. Am. Exot. Anim. Pract. 2: 741-776.

6. Harms, C. A., T. Ross, and A. Segars. 2002. Plasma biochemistry of bonnethead sharks. Vet. Clin. Pathol. 31: 111-115.

7. Hartman, F. A., L. A. Lewis, K. A. Brownell, F. F. Shelden, and R. F. Walther. 1941. Some blood constituents of the normal skate. Physiol. Zool. 14: 476-486.

8. Hoese, H. D., and R. H. Moore. 1977. Fishes of the Gulf of Mexico: Texas, Louisiana, and Adjacent Waters. Texas A\&M University Press, College Station, Texas.

9. HotSpotsCharts, LLC. Sea Surface Temperature Charts. 1 June 2002 AM reading and 15 July 2002 reading. Web page: http://www.sstcharts.com/archives.shtml. Accessed: September 2003.

10. Mandrup-Poulsen, J. 1981. Changes in selected blood serum constituents, as a function of salinity varia- 
tions, in the marine elasmobranch, Sphyrna tiburo. Comp. Biochem. Physiol. 70A: 127-131.

11. Manire, C., R. Hueter, E. Hull, and R. Spieler. 2001. Serological changes associated with gill-net capture and restraint in three species of sharks. Trans. Am. Fish. Soc. 130: 1038-1048.

12. Moyle, P. B., and J. J. Cech, Jr. 1988. Fishes: An Introduction to Ichthyology, 2nd ed. Prentice Hall, Englewood Cliffs, New Jersey.

13. Murray, R. W., and W. T. W. Potts. 1960. The composition of the endolymph, perilymph, and other body fluids of elasmobranchs. Comp. Biochem. Physiol. 2: 65-75.

14. Nelson, J. S. 1994. Fishes of the World, 3rd ed. John Wiley \& Sons, New York, New York.

15. Olson, K. R. 1998. The cardiovascular system. In: Evans, D. H. (ed.). The Physiology of Fishes, 2nd ed.. CRC Press, Boca Raton, Florida.

16. Pickering, A. D., T. D. Pottiger, and P. Christie. 1982. Recovery of brown trout, Salmo trutta, L., from acute handling stress: a time course study. J. Fish Biol. 20: 229-244.

17. Rice, W. R. 1999. Analyzing tables of statistical tests. Evolution 43: 223-225.

18. Robins, R. C., G. Ray, and J. Douglass. 1986. Atlantic Coast Fishes. Peterson's Field Guide. Houghton Mifflin Press, New York, New York.
19. Schmidt-Neilsen, Knut. 1990. Animal Physiology: Adaptation and Environment, 4th ed. Cambridge University Press, New York, New York.

20. Smith, H. W. 1929. The composition of the body fluids of elasmobranches. J. Biol. Chem. 81: 407-419.

21. Stoskopf, M. K. 1993. Clinical pathology of sharks, skates, and sting rays. In: Stoskopf, M. K. (ed.). Fish Medicine. W. B. Saunders Co., Philadelphia, Pennsylvania.

22. Stoskopf, M. K. 2000. Normal hematology of elasmobranches. In: Feldman, B., J. Ziniki, and N. Jain (eds.). Schalm's Veterinary Hematology. Lippincott Williams \& Wilkins, Philadelphia, Pennsylvania.

23. Thorson, T. B., C. M. Cowan, and D. E. Watson. 1967. Potamotrygon spp.: elasmobranchs with low urea content. Science 158: 375-377.

24. Wells, R. M. G., and P. S. Davie. 1985. Oxygen binding by the blood and hematological effects of capture stress in two big game-fish: mako shark and striped marlin. Comp Biochem. Physiol 81A: 643-646.

25. Wells, R. M. G., R. H. McIntyre, A. K. Morgan, and P. S. Davie. 1986. Physiological stress responses in big gamefish after capture: observations on plasma chemistry and blood factors. Comp. Biochem. Physiol. 84: 565-571.

Received for publication 5 November 2003 